\title{
Effects of Supplemental Irrigation on Crop Yields: Case Study Kales (Brassica Oleracea) Crop
}

\author{
Jedidah Maina1*, Shem Wandiga', Benjamin Gyampoh', Charles Gachene² \\ 1 Institute for Climate Change and Adaptation, University of Nairobi, Kenya \\ 2 Department of Land Resource Management \& Agricultural Technology, University of Nairobi, Kenya \\ * Corresponding author's e-mail: jedidahwm@gmail.com
}

\begin{abstract}
The aim of this study was to investigate the effects that supplemental irrigation (SI) has on the Kale (Brassica Oleracea) crop yields as compared to the wholly rain-fed crop. The experiments were conducted in Kieni, Central Kenya where the rainfall pattern was bimodal. The planting for rain-fed crops was done in three blocks, each measuring $10 \times 1 \mathrm{~m}$ with a spacing of $30 \mathrm{~cm}$ between plants and $45 \mathrm{~cm}$ between the rows of plants; the procedure was repeated for the crops receiving SI. The average weekly yields were computed for both crops for each season comprised of 14 weeks. The average weekly yields were subjected to Analysis of Variance (ANOVA) to determine whether the average yields from the rain-fed and supplemental irrigated crops were statistically different. This was done with MS Excel 2016 spread sheets by setting a statistical level of significance of 5\%. The F value was 17.94 higher than the critical value of 4.01 while the $\mathrm{P}$-value of $9 \times 10^{-5}$ was lower than the $5 \%$ level of confidence meaning that there was a significant difference in the yield means of the rain-fed and SI crops. The total rain-fed crop yields for the period was $147.0 \mathrm{Kgs}$ and that of the one under SI was $238 \mathrm{Kgs}$, an increase of about $62 \%$. Therefore, supplemental irrigation can be adopted in the areas where rainfall trends are declining to increase the crop yields when all other factors remain constant for farmers - to increase resilience.
\end{abstract}

Keywords: supplemental irrigation, rain-fed, crop yields, level of significance

\section{INTRODUCTION}

The countries in the Sub-Saharan Africa (SSA) in the recent years have been experiencing an increase in temperature while rainfall has continued to be more variable due to the changing climate contributing to crop failure under rain-fed agricultural systems. Kaluli et al. [2012] reported that $80 \%$ of Kenya are arid and semi-arid areas experiencing low poorly distributed and variable rainfall in the ranges of 100-600 mm per year making the water management an essential part of agriculture for a country that earns $60 \%$ of the revenue from export [Ngigi et al., 2011]. According to the Economic Survey Report Highlight of 2014, the country's agricultural sector growth fell from $4.2 \%$ in 2012 to $2.9 \%$ in 2013 due to inadequate rainfall received in some grain growing areas (Economic Survey, 2014).

According to Kulshreshtha [2011], the changes in rainfall will directly affect the quantity and quality of produce and in Central Kenya significant changes of rainfall trends have been observed. Karienye et al. [2012] argues that in the same area, rainfall received has been declining every 3 to 4 years while since 1960s, maximum temperatures have been rising to the magnitude of $0.1-0.7^{\circ} \mathrm{C}$; therefore, increasing evaporation [GOK, 2010]. In Nyeri County, most of the land is under private smallholder farms producing vegetables and fruits for export as well as for local consumption, though the area has been experiencing water scarcity for agriculture due to the spatial and temporal rainfall variability which affects the crop production [CGoN, 2013; 
Karienye et al., 2012; Nderitu et al., 2016]. In the study area of Kieni which is located within Nyeri County in Central Kenya, Nderitu et al. [2016] reported that between 1985-2015 long rains that falls from March to May have been decreasing.

According to Leuzinger et al. [2015] and Tietjen et al. [2017], plant growth and development is affected by the level of soil moisture which is in turn affected by the rainfall patterns and air temperature changes and each crop has a defined range of highest and lowest soil moisture condition for observable growth to occur. Therefore, as Knowles et al. [2006] reported, the soil moisture content may be reduced considerably due to the loss of soil water from evaporation. Beyond a certain point, increased moisture stress adversely affects the plant growth pollination and reproduction purposes [Sacks and Kucharik, 2011]. Therefore, this water stress calls for the crops to be grown under the SI system which is essentially adding small amounts of water to the growing crops when rains fail.

Hatibu et al. [2006] reported that the plots under SI realised about $1.5 \mathrm{t} / \mathrm{ha}$ of grains yields in a season of a very dry spell in a pilot experiment while no grains were harvested under the rain-fed system. According to Fox and Rochstrom [2003], an on-farm experiment in SAHEL whereby the supplemental irrigated crops resulted in a 56.5\% increase in yields while Oweis [1997] reported that in Syria, rain-fed average wheat yields were only $1.25 \mathrm{t} / \mathrm{ha}$ and the same crop yielded $3 \mathrm{t} / \mathrm{ha}$ under SI, and in Turkey, the yields ranged from 0.9-2.5 t/ha and from 3.0-4.5 t/ha.

A study conducted by Agricultural Research Center in Iraq (IPA) and international Center for Agricultural Research in Dry Areas (ICARDA) showed that both yield and water productivity increased by applying SI in conjunction with rainfall and by using $68 \mathrm{~mm}$ of irrigation water for rain-fed wheat, the yield increased by more than $100 \%$ in one season [Adary et al., 2002]. According to Oweis and Hachum [2012], more water is needed when rainfall is low with increased yields even when rainfall is as high as $500 \mathrm{~mm}$. According to IPCC (2014), the scientific consensus established is that up to 2050, the water-constrained tropical regions will undergo crop yield decreases; therefore, in the study area, which is a dry tropical area, the crops yields under rain-fed system are expected to decrease if SI is not implemented.

\section{MATERIALS AND METHODS}

The experimental plot for this study was selected from a farmer's farm among others for being the most active member of the community. However, since the area experiences a bimodal rainfall pattern, occurring in March April May (MAM) and October November December (OND), the first planting season occurred in September-December 2017, the second in MAM of 2018 while the third season was in OND of the same year.

The nursery bed which was $20 \mathrm{~cm}$ high $1 \mathrm{~m}$ wide and $2 \mathrm{~m}$ long was prepared by first digging about $20 \mathrm{~cm}$ deep into the soil, thus loosening it. Two buckets of organic manure were thoroughly mixed with the soil and then the bed leveled off to make a flat surface before watering it with a watering can. Rows $20 \mathrm{~cm}$ apart and $0.5 \mathrm{~m}$ deep were made on the bed with a stick and seeds planted 1 hour after watering. The nursery bed was then covered with clean dry grass to reduce evaporation and to prevent the seeds runoff during watering. Watering was done twice a day, in the morning and evening. Seeds germinated after 7 days, whereby the grass mulch was removed and raised to about $60 \mathrm{~cm}$ above the nursery bed to provide shade to the growing seedlings. Watering continued twice a day for further two weeks when it was gradually reduced to once a week until plants were ready for transplanting at 6 weeks.

The planting of Kales was divided into two parts. The rain-fed crop was planted at the beginning of the season while the crop under SI was planted at the middle of the rainy season for it to utilize the rains for the first 6 weeks or so depending on the duration of the rainy season and then drip irrigated when the rainy season ended and the crop started showing signs of water stress like wilting. SI was done after every three days for an average of 30 minutes in the evenings when it was not too hot and therefore the rate of evaporation was reduced.

The planting for the rain fed crops was done in three blocks, each measuring $10 \times 1 \mathrm{~m}$ with a spacing of $30 \mathrm{~cm}$ between plants and $45 \mathrm{~cm}$ between rows of plants. This procedure was repeated for the crops receiving SI when it was time for their transplanting from the nursery bed. Weeding on the bed was done whenever the weeds grew by uprooting them by hands so that the soil was not disturbed and also reduce the soil losing too much moisture. The average weekly yields (harvesting 
was done weekly) were computed for both crops for each season each comprising of 14 weeks. The average weekly yields were subjected to Analysis of Variance (ANOVA analysis) in order to determine whether the average yields from the rain-fed and supplemental irrigated crops are statistically different. This was done with MS Excel 2016 spread sheets by setting a statistical level of significance of 5\%. The ANOVA analysis was applied to the average weekly yields.

\section{RESULTS}

Table 1 shows the weekly average harvests or yields for both the rain-fed crops and the crops receiving SI over a period of 14 weeks. The ANOVA analysis in Table 2 showed a total sum of $147.0 \mathrm{Kgs}$, weekly average of $3.8 \mathrm{Kgs}$ and a variance of 10.3 $\mathrm{Kgs}$, while the irrigated crop had a total sum of $238.0 \mathrm{Kgs}$, weekly average of $5.67 \mathrm{Kgs}$ and a variance of $20 \mathrm{Kgs}$. The rain-fed and irrigated crops means had an $\mathrm{F}$ value of 17.94 which was greater than the F critical of 4.01 while their P-value of $9 \times 10^{-5}(0.00009)$ was less than the 0.05 significant level and therefore the average crop yields for both the rain-fed and irrigated crops were significantly different as shown in table 3 . The weekly P-value computed was $3 \times 10^{-12}$ which was also lower than the significant level of 0.05 which showed that the yields were changing from one week to the other for both crops. On the other hand, the interaction p-value was 0.96 , higher than the significant level that meant that the averages for both rain-fed and irrigated crop yields were not changing across the 14-week period (Table 3).

\section{DISCUSSION}

The yields had sum total of $147 \mathrm{Kgs}$ for the rain-fed crops and $238 \mathrm{Kgs}$ for the supplemental irrigated crops, an increase of $62 \%$. In turn, the weekly average for the rain-fed crops was $3.5 \mathrm{Kgs}$ against $5.7 \mathrm{Kgs}$ for the crop under SI. Therefore, crops yield increased when the same crop was

Table 1. 14-weeks average yields

\begin{tabular}{|c|c|c|c|c|c|c|c|c|c|c|c|c|c|c|}
\hline \multirow{2}{*}{ Condition } & \multicolumn{14}{|c|}{ Weeks } \\
\hline & 1 & 2 & 3 & 4 & 5 & 6 & 7 & 8 & 9 & 10 & 11 & 12 & 13 & 14 \\
\hline Rain-fed & 4 & 6 & 5.5 & 6.5 & 6 & 4.5 & 4 & 3.5 & 3 & 3 & 1 & 0 & 0 & 0 \\
\hline Rain-fed & 14 & 10 & 10 & 7.5 & 6.5 & 4 & 3.5 & 3 & 1.5 & 1.5 & 0 & 0 & 0 & 0 \\
\hline Rain-fed & 6 & 6 & 5 & 4.5 & 4 & 4 & 3 & 2.5 & 2 & 1.5 & 0 & 0 & 0 & 0 \\
\hline Irrigated & 5 & 5.5 & 7 & 12 & 11 & 9 & 8 & 5 & 3.5 & 3 & 2.5 & 0 & 0 & 0 \\
\hline Irrigated & 16 & 15.5 & 14 & 12 & 8 & 5 & 4 & 3 & 1.5 & 0 & 0 & 0 & 0 & 0 \\
\hline Irrigated & 11 & 10 & 9.5 & 8.5 & 7.5 & 7 & 6.5 & 5.5 & 4.5 & 4.5 & 4.5 & 3.5 & 3 & 2 \\
\hline
\end{tabular}

Table 2. ANOVA Analysis-Two-Factor with Replication

\begin{tabular}{|c|c|c|c|c|c|c|c|c|c|c|c|c|c|c|c|}
\hline \multirow{2}{*}{ Summary } & \multicolumn{15}{|c|}{ Weeks } \\
\hline & 1 & 2 & 3 & 4 & 5 & 6 & 7 & 8 & 9 & 10 & 11 & 12 & 13 & 14 & Total \\
\hline \multicolumn{16}{|l|}{ Rain-fed } \\
\hline Count & 3 & 3 & 3 & 3 & 3 & 3 & 3 & 3 & 3 & 3 & 3 & 3 & 3 & 3 & 42 \\
\hline Sum & 24 & 22 & 20.5 & 18.5 & 16.5 & 12.5 & 10.5 & 9.0 & 6.5 & 6.0 & 1.0 & 0.0 & 0.0 & 0.0 & 147.0 \\
\hline Average & 8 & 7.3 & 6.8 & 6.2 & 5.5 & 4.2 & 3.5 & 3.0 & 2.2 & 2.0 & 0.3 & 0.0 & 0.0 & 0.0 & 3.5 \\
\hline Variance & 28 & 5.3 & 7.6 & 2.3 & 1.8 & 0.1 & 0.3 & 0.3 & 0.6 & 0.8 & 0.3 & 0.0 & 0.0 & 0.0 & 10.3 \\
\hline \multicolumn{16}{|l|}{ Irrigated } \\
\hline Count & 3 & 3 & 3 & 3 & 3 & 3 & 3 & 3 & 3 & 3 & 3 & 3 & 3 & 3 & 42 \\
\hline Sum & 32.0 & 31.0 & 30.5 & 32.5 & 26.5 & 21.0 & 18.5 & 13.5 & 9.50 & 7.50 & 7.00 & 3.50 & 3.0 & 2.0 & 238.0 \\
\hline Average & 10.7 & 10.3 & 10.2 & 10.8 & 8.8 & 7.0 & 6.2 & 4.5 & 3.2 & 2.5 & 2.3 & 1.2 & 1.0 & 0.7 & 5.7 \\
\hline Variance & 30.3 & 25.1 & 12.6 & 4.1 & 3.6 & 4.0 & 4.1 & 1.8 & 2.3 & 5.3 & 5.1 & 4.1 & 3.0 & 1.3 & 20.0 \\
\hline \multicolumn{16}{|l|}{ Total } \\
\hline Count & 6 & 6 & 6 & 6 & 6 & 6 & 6 & 6 & 6 & 6 & 6 & 6 & 6 & 6 & \\
\hline Sum & 56 & 53 & 51 & 51 & 43 & 33.5 & 29 & 22.5 & 16 & 13.5 & 8.0 & 3.5 & 3.0 & 2.0 & \\
\hline Average & 9.3 & 8.8 & 8.5 & 8.5 & 7.2 & 5.6 & 4.8 & 3.8 & 2.7 & 2.3 & 1.3 & 0.6 & 0.5 & 0.3 & \\
\hline Variance & 25.5 & 14.9 & 11.4 & 9.1 & 5.5 & 4.1 & 3.9 & 1.5 & 1.5 & 2.5 & 3.4 & 2.0 & 1.5 & 0.7 & \\
\hline
\end{tabular}


Table 3. ANOVA Analysis

\begin{tabular}{|l|c|c|c|c|c|c|}
\hline \multicolumn{1}{|c|}{ Source of Variation } & SS & $d f$ & $M S$ & $F$ & $P$-value & F crit \\
\hline Sample(Condition) & 98.58333 & 1 & 98.58 & 17.94 & $9 \mathrm{E}-05$ & 4.01 \\
\hline Columns (Weeks) & 900.9167 & 13 & 69.30 & 12.61 & $3 \mathrm{E}-12$ & 1.90 \\
\hline Interaction & 29.75 & 13 & 2.29 & 0.42 & 0.96 & 1.90 \\
\hline Within & 307.6667 & 56 & 5.49 & & & \\
\hline Total & 1336.917 & 83 & & & & \\
\hline
\end{tabular}

grown under SI conditions. Fox and Rochstrom [2003] had reported an increase of $56.5 \%$ of crop yields that receive SI as compared to those under rain-fed in an experiment in SAHELwhile Oweis [1997] reported that in Syria wheat crop under SI realised yields of $3 \mathrm{t} / \mathrm{ha}$ and the same crop under rain-fed conditions had yields of only $1.25 \mathrm{t} / \mathrm{ha}$. A study conducted by Agricultural Research Center in Iraq (IPA) and international Center for Agricultural Research in Dry Areas (ICARDA) showed that by using only $68 \mathrm{~mm}$ of irrigation water for the rain-fed wheat, the yield increased in one season from $2.16 \mathrm{t} / \mathrm{ha}$ to $4.61 \mathrm{t} / \mathrm{ha}$ [Adary et al, 2002] as mentioned in the introduction section.

\section{CONCLUSION}

The ANOVA analysis of crop yields showed that the significant levels were lower than the confidence level set at 0.05 indicating a significant difference between the average rain-fed crop yields and the average yields of the crops that had received SI. The average weekly crop yields of the crops that had received SI from the previously stored water showed an increase of about $62 \%$ which is quite substantial. This is therefore an indication that supplemental irrigation can increase the crop yields if applied properly and constitute a better way of efficiently managing agricultural water.

\section{REFERENCES}

1. Adary, A., Hachum, A., Oweis, T. and Pala, M. 2002. Wheat productivity under SI in Northern Iraq.

2. CGoN C.G.o.N. 2013. Strategic Plan 2013-2018 in: L. Department of Agriculture , Fisheries, and Co-operative Development: (Ed.).

3. Fox, P., and Rockström, J. 2003. Supplemental irrigation for dry-spell mitigation of rainfed agriculture in the Sahel. Agricultural water management, 61(1), 29-50.Esri, G.I.S., 2006. Mapping Software. ArcGIS: http://www. esri. com/software/arcgis.
4. GoK 2010. National Climate Change Response Strategy, in: M. o. E. a. M. Resources (Ed.), Nairobi.

5. Government of Kenya 2014. 2014 Economic Survey Report Highlights. Ministry of Devolution and Planning.

6. Hatibu, N., Mutabazi, K., Senkondo, E. M., \& Msangi, A. S. K. 2006. Economics of rainwater harvesting for crop enterprises in semi-arid areas of East Africa. Agricultural Water Management, 80(1-3), 74-86.

7. IPCC. 2014. Climate Change 2014: Impacts, Adaptation, and Vulnerability. Part A: Global and Sectoral Aspects. Contribution of Working Group II to the Fifth Assessment Report of the Intergovernmental Panel on Climate Change, in: C. B. Field, et al. (Eds.), (eds.), Cambridge University Press, Cambridge, United Kingdom and New York, NY, USA. pp. 1132.

8. Kaluli, J. W., Nganga, K., Home, P. G., Gathenya, J. M., Muriuki, A. W. and Kihurani, A. W. 2012. Effects on rainwater harvesting and drip irrigation on crop performance in an Arid and Semi-arid environment. JAGST Vol 14(2) 2012.

9. Karienye, K.D., Mwangi, G.P., Kaguai, W.I., Waweru, E. and Muthoni, M.D. 2012. Impact of Climate Variability on Food Security and Biodiversity Conservation in Nyeri County, Kenya.

10. Knowles, N., Dettinger, M.D., and Cayan, D.R. .2006. Trends in snowfall versus rainfall in the western United States. Journal of Climate 19:4545-4559.

11. Kulshreshtha, S.N. 2011. Climate change, prairie agriculture, and prairie economy: the new normal. Canadian Journal of Agricultural Economics/Revue canadienne d'agroeconomie 59, 19-44.

12. Leuzinger, S., Fatichi, S., Cusens, J., Körner, C. and Niklaus P.A. 2015. The 'island effect' in terrestrial global change experiments: a problem with no solution? AoB Plants 7.

13. Nderitu, M., Oludhe, C., Ali, A.A., Omondi, P. and Makui, P. 2016. Analysis of Rainfall and Temperature Variability in Kieni; Nyeri County. International Journal of Innovative Research and Development 5.

14. Ngigi, S., Kariuke, J. and Allan, K. 2011. Rainwater harvesting and management for improving agricultural productivity in Arid and Semi - Arid Areas of Kenya. 
15. Oweis, T. 1997. Supplemental irrigation: A highly efficient water-use practice. ICARDA.

16. Oweis, T. and Hachum, A. 2012. SI, a highly efficient water-use practice. ICARDA, Aleppo, Syria. iv +28 pp.

17. Sacks, W.J. and Kucharik, C.J. 2011. Crop management and phenology trends in the U.S. corn belt: Impacts on yields, evapotranspiration and energy balance. Agriculture, Forestry and Meteorology 151:882-894.

18. Tietjen, B., Schlaepfer, D.R., Bradford, J. B., Lauenroth, W. K., Hall, S. A., Duniway, M. C., Hochstrasser, T., Jia, G., Munson, S. M. and Pyke, D. A. 2017. Climate change- induced vegetation shifts lead to more ecological droughts despite projected rainfall increases in many global temperate drylands. Global Change Biology 23:2743-2754. 